\title{
Coprinopsis rugosomagnispora: a distinct new coprinoid species from Poland (Central Europe)
}

\author{
Błażej Gierczyk $^{1}$ - Pamela Rodriguez-Flakus ${ }^{2}$ Marcin Pietras ${ }^{3,4}$ - Mirosław Gryc ${ }^{5}$. \\ Waldemar Czerniawski ${ }^{6}$ Marcin Piątek ${ }^{7}$
}

Received: 3 November 2016/Accepted: 31 March 2017/Published online: 28 April 2017

(c) The Author(s) 2017. This article is an open access publication

\begin{abstract}
A new coprinoid fungus, Coprinopsis rugosomagnispora, is described from Poland (Central Europe). Its macromorphological characters are similar to species belonging to the subsection Nivei of Coprinus s.l. However, C. rugosomagnispora has unique micromorphological characters: very large, ornamented spores, voluminous basidia and cystidia, and smooth veil elements. The large spores and pattern of spore ornamentation (densely pitted) make this species unique within all coprinoid species described so far. The structure (arrangement and shape) of veil elements in $C$. rugosomagnispora is intermediate between members of the subsections Nivei and Lanatuli of Coprinus s.l. Molecular phylogenetic analyses, based on single-locus (ITS) maximum likelihood and Bayesian
\end{abstract}

Handling editor: Miroslav Kolařík.

Błażej Gierczyk

hanuman@amu.edu.pl

1 Faculty of Chemistry, Adam Mickiewicz University in Poznań, Umultowska 89b, 61-614 Poznań, Poland

2 Laboratory of Molecular Analyses, W. Szafer Institute of Botany, Polish Academy of Sciences, Lubicz 46, 31-512 Kraków, Poland

3 Department of Plant Taxonomy and Nature Conservation, University of Gdańsk, Wita Stwosza 59, 80-308 Gdańsk, Poland

4 Laboratory of Symbiotic Associations, Institute of Dendrology, Polish Academy of Sciences, Parkowa 5, 62-035 Kórnik, Poland

5 Elektryczna 1, 16-030 Ogrodniczki, Poland

6 Tyniecka 28, 32-050 Skawina, Poland

7 Department of Mycology, W. Szafer Institute of Botany, Polish Academy of Sciences, Lubicz 46, 31-512 Kraków, Poland evolutionary trees recovered C. rugosomagnispora within a lineage containing species having morphological characters of the subsection Lanatuli (though within the so-called Atramentarii clade) that contradicts its morphological similarity to members of the subsection Nivei.

Keywords Agaricales - Coprinopsis - Coprinoid fungi . Molecular phylogeny · Spore ornamentation · Taxonomy

\section{Introduction}

The coprinoid fungi are a highly diverse and polyphyletic group of the order Agaricales, which species show a unique set of characters: presence of dark spores, deliquescent basidiocarps that often undergo autolysis, and pseudoparaphyses in the hymenium (Uljé 2005). These species were previously classified in one genus, Coprinus Pers., but molecular studies revealed that the genus is split into four main lineages assigned to four genera: Coprinus s. s., Coprinellus P.Karst., Coprinopsis P.Karst., and Parasola Redhead, Vilgalys \& Hopple (Hopple and Vilgalys 1999; Moncalvo et al. 2002; Padamsee et al. 2008; Larsson and Örstadius 2008; Nagy et al. 2009, 2010a, b, 2011, 2012, 2013a). The coprinoid fungi with a veil composed of smooth, (sub)globose elements, and lacking pileocystidia belonged to subsection Nivei of Coprinus s.l. (Citérin 1992; Uljé 2005), now included in the genus Coprinopsis (Hopple and Vilgalys 1999; Moncalvo et al. 2002). In Europe, about 20 species from this subsection were reported so far (Uljé 2005; Vesterholt 2012). It cannot be ruled out that at least some of them are probably collective species, e.g., Coprinopsis cortinata (J.E.Lange) Gminder (Uljé 2005). This view may be supported by the molecular analyses of Keirle et al. (2004), which revealed significant genetic 
diversity among the collections of $C$. cordispora (T.Gibbs) Gminder originating from Europe and Hawaii.

In this work, a distinct species of Coprinopsis is described on the basis of morphological and molecular analyses that differ from all other known species of the subsection Nivei of Coprinus s.l. (Citérin 1992; Uljé 2005) as well as from remaining recognized Coprinopsis species. This new species was collected several times in two different regions of Poland, indicating that unknown coprinoid fungi can still be found, even in relatively wellstudied regions such as Europe.

\section{Materials and methods}

\section{Specimen sampling, morphological analyses, and nomenclature of subsections}

The study is based on dried herbarium specimens. The holotype is deposited in the fungal collection of the W. Szafer Institute of Botany, Polish Academy of Sciences, Kraków, Poland (KRAM F), while isotype and remaining specimens are in the personal collection of the first author (BG). The material was studied by light microscope (LM) and scanning electron microscope (SEM). For LM, samples were rehydrated in aqueous ammonia solution $(10 \%)$ and stained with Congo red ( $0.5 \%$ in aqueous ammonia). Observations, measurements, and micrographs were made using a Bresser Science TRM 301 light microscope. Drawings of microcharacters were made from micrographs taken with a Bresser MicroCam 5.0 digital camera. All measurements were taken directly through the light microscope under an oil immersion objective $(100 \times)$. The spore dimensions were established from measurements of 50 randomly selected, well-formed spores (the deformed or atrophied spores were excluded from analysis) per collection. The $95 \%$ population limits for the mean were calculated, and the lower and upper values are given. For basidia and cystidia, the extreme size values were presented. For these structures, dimensions were obtained after measuring 25 elements. For SEM, fragments of dried fungal hymenium were glued onto carbon tabs and fixed to an aluminum stub with double-sided transparent tape. The stubs were sputter-coated with carbon using a Cressington sputter coater and viewed under a Hitachi S-4700 scanning electron microscope, with a working distance of ca. $12 \mathrm{~mm}$. SEM micrographs were taken in the Laboratory of Field Emission Scanning Electron Microscopy and Microanalysis at the Institute of Geological Sciences of Jagiellonian University (Kraków). Color notation used in the description is according to Kornerup and Wanscher (1984). In the following text, the names of subsections (Alachuani, Lanatuli, Narcotici, Nivei) refer to
Fig. 1 Phylogenetic relationship among sampled Coprinopsis species, including the newly described Coprinopsis rugosomagnispora, based on Bayesian inference analyses of ITS sequences. The support values (ML-BP $\geq 60 \%$, Bayesian analysis- $\mathrm{PP} \geq 0.7$ ) are placed above branches. Thickened branches represent clades well supported at least in one of the analyses (ML-BP $\geq 70 \%$, Bayesian analysis$\mathrm{PP} \geq 0.9)$. The branch lengths denoted by double slash $(/ /)$ were shortened $(2 \times, 7 \times, 2 \times, 4 \times$, respectively, starting from the top to the bottom of the tree) to improve visualization. The morphological subsections of Coprinus s.l. are demarcated with colored squares, and three Agrocybe species were included as outgroup. The species assigned to the so-called Atramentarii clade by Nagy et al. (2013a) are demarcated within lineage containing species showing characters of the morphological subsection Lanatuli

morphological subsections of Coprinus s.l. as delineated by Uljé (2005).

\section{DNA extraction, PCR amplification, and sequencing}

Fungal DNA was extracted from a small part of basidiocarp representing the holotype of Coprinopsis rugosomagnispora. DNA was extracted using the GeneMATRIX Plant and Fungi DNA Purification Kit (EURx, Poland), following the manufacturer's protocols. The final PCR reaction volume was $10 \mu \mathrm{l}$ composed of $4 \mu \mathrm{l}$ DNA template, $0.5 \mu \mathrm{l}$ of each primer ITS5 and ITS4 (White et al. 1990), and $5 \mu 1$ Type-it Microsatellite PCR Kit (Qiagen, Germany). PCR amplification was performed using the following thermocycling conditions: an initial denaturing step at $95{ }^{\circ} \mathrm{C}$ for $15 \mathrm{~min}$, followed by 35 cycles at $95{ }^{\circ} \mathrm{C}$ for $30 \mathrm{~s}, 55{ }^{\circ} \mathrm{C}$ for $30 \mathrm{~s}, 72{ }^{\circ} \mathrm{C}$ for $1 \mathrm{~min}$, and a final extension of $10 \mathrm{~min}$ at $72{ }^{\circ} \mathrm{C}$. PCR product was visualized by running $5 \mu \mathrm{l}$ DNA amplicon on $1.5 \%$ agarose gel for $30 \mathrm{~min}$. The PCR product was sequenced at the Laboratory of Molecular Biology of Adam Mickiewicz University in Poznań. The obtained sequences fragments were checked, assembled, and manually edited using Geneious Pro, version 8.0. (Biomatters Ltd). The ITS sequence obtained in this study was deposited in the NCBI's GenBank database (http://www.ncbi.nlm.nih.gov/genbank) with accession number KX276859.

\section{Phylogenetic analyses}

The ITS sequence from the holotype of Coprinopsis rugosomagnispora generated in this study was checked by a Blast search (Altschul et al. 1997) against the ITS sequences deposited in GenBank to reveal closely related species. Subsequently, the sequence was analyzed within a dataset covering all Coprinopsis species available in GenBank, reduced to one sequence per species (with the exception of Coprinopsis lagopus (Fr.) Redhead, Vilgalys \& Moncalvo s.1.), and including sequences generated by 


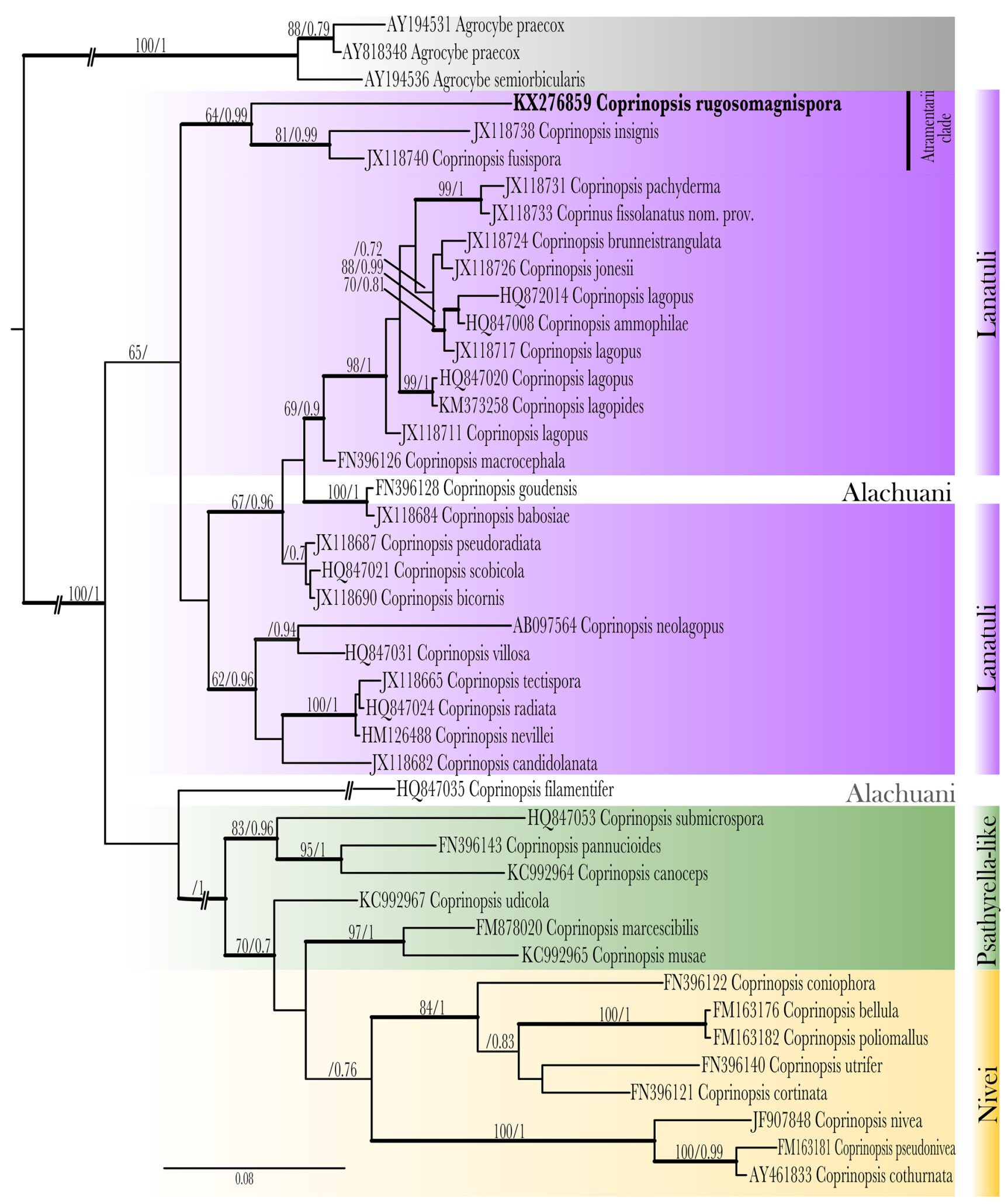


experts of Coprinopsis taxonomy (Keirle et al. 2004; Navarro-González et al. 2006; Garcia and Vellinga 2010; Nagy et al. 2010a, 2011, 2013a, b; Geml et al. 2012; Osmundson et al. 2013; Ruiz et al. 2013; Örstadius et al. 2015; Elwess et al. 2016; and some unpublished sequences available in GenBank). A total of 85 sequences were aligned using MUSCLE algorithm and default settings (Edgar 2004) to obtain preliminary hypothesis on the phylogenetic placement of Coprinopsis rugosomagnispora (data not shown). For the final phylogeny, we reduced the dataset to 40 sequences representing lineage containing a new species and most closely related Coprinopsis species (from the subsection Lanatuli) and some more distantly related species (from other subsections, among others from the subsection Nivei). The three sequences of Agrocybe Fayod were chosen as outgroup following Nagy et al. (2013b). GenBank accession numbers are given in Fig. 1 and in Table 1. The alignment was deposited in TreeBASE (S20797).

Phylogenetic analyses were carried out using maximum likelihood (ML) implemented in RaxmlGUI version 0.9 beta 2 (Silvestro and Michalak 2012) and Bayesian inference in MrBayes version 3.1.2 (Huelsenbeck and Ronquist 2003). The nucleotide substitution models were separately selected for each part of the ITS region (ITS1, 5.8S, ITS2) inferred with PartitionFinder version 1.0.1 (Lanfear et al. 2012) using the Bayesian Information Criterion (BIC) as optimality model criterion in a greedy search. In the likelihood analyses, a GTRGAMMAI substitution model and 1000 bootstrap resamples in separate partitions were performed, and for MCMC analyses, three independent parallel runs were started each with four incrementally heated (temperature $=0.15$ ) chains. This Markov chain was allowed to run for $100 \mathrm{M}$ generations sampling every 1000th tree and a 50\% as the burn-in factor. Resulting phylogenetic trees were visualized in TreeView software (Page 1996).

\section{Results}

\section{Morphological analyses}

The morphological characteristics of new species, Coprinopsis rugosomagnispora, are included in the species description and depicted in section Taxonomic treatment.

\section{Phylogenetic analyses}

The current phylogenetic studies included 43 sequences: 40 sequences of Coprinopsis species and three outgroup sequences of Agrocybe species (following Nagy et al. 2013b), with 514 unambiguously aligned nucleotide positions. The consensus tree topology and branch supports were assessed under maximum likelihood (ML) and Bayesian inference analyses. Although the consensus tree topology under ML and Bayesian inference yielded a similar pattern, the Bayesian phylogenetic tree is presented in this study, in which several major Coprinopsis clades are clearly delimitated, and the ML bootstrap values and posterior probabilities are placed above moderately or wellsupported branches (Fig. 1).

The molecular analyses revealed Coprinopsis rugosomagnispora as sister species to C. insignis (Peck) Redhead, Vilgalys \& Moncalvo and C. fusispora L.Nagy, Vágvölgyi \& T.Papp, members of the Atramentarii clade (Nagy et al. 2013a), which altogether formed a lineage showing strong support in the Bayesian analysis $(\mathrm{PP}=0.99)$ and moderate support in $\mathrm{ML}$ analysis $(\mathrm{BP}=64 \%)$. The clade is sister and basal to the large assemblage of 18 Coprinopsis species belonging to the subsection Lanatuli of Coprinus s.l. (Lange 1915; Uljé 2005). Coprinopsis goudensis (Uljé) Redhead, Vilgalys \& Moncalvo, a member of the subsection Alachuani of Coprinus s.l., is nested inside this assemblage and therefore probably should be reassigned to subsection Lanatuli. The remaining sampled Coprinopsis species (sister to the lineage containing members of the subsection Lanatuli) were split into distinct groups: (1) Coprinopsis filamentifer (Kühner) Redhead, Vilgalys \& Moncalvo (subsection Alachuani) that forms a long branch by its own, (2) a highly supported paraphyletic clade containing species with morphologies similar to members of the genus Psathyrella (Fr.) Quél. (we informally call this lineage 'Psathyrella-like'), and (3) a not supported lineage including species from the subsection Nivei (Fig. 1).

\section{Discussion}

Many of the recently described coprinoid fungi differ only slightly from the earlier recognized species or are even indistinguishable without molecular data (Raut et al. 2011; Nagy et al. 2013a). By contrast, Coprinopsis rugosomagnispora described here has a unique and distinct combination of characters (Figs. 2, 3). Its macromorphological characters, such as small dimensions of basidiocarps and granular veil forming conical warts, are similar to that of Coprinopsis cordispora and morphologically similar species in the subsection Nivei. Likewise, the smooth veil elements suggest affinity of $C$. rugosomagnispora to members of this subsection. On the other hand, the structure (arrangement and shape) of veil elements in C. rugosomagnispora is intermediate between that of members in the subsections Nivei and Lanatuli. Specifically, veil elements are arranged in chains as in the subsection Lanatuli (in the subsection Nivei, veil elements are composed of 
Table 1 List of species used in the molecular analyses, with countries of origin, collector, voucher information, GenBank accession numbers (ITS), and references

\begin{tabular}{|c|c|c|c|c|c|}
\hline Species & Country & Collector & Voucher & $\begin{array}{l}\text { GenBank acc. no. } \\
\text { (ITS) }\end{array}$ & References \\
\hline Agrocybe praecox & USA & N/A & MSC 378486 & AY194531 & Hallen et al. (2003) \\
\hline Agrocybe praecox & N/A & N/A & AFTOL-ID 728 (WTU) & AY818348 & Yang et al. (2005) \\
\hline Agrocybe semiorbicularis & USA & N/A & MSC 378490 & AY194536 & Hallen et al. (2003) \\
\hline Coprinopsis ammophilae & N/A & R. Watling & Watling 24982 & HQ847008 & Nagy et al. (2013b) \\
\hline Coprinopsis babosiae & Hungary & L. Nagy & SZMC-NL-2641 & JX118684 & Nagy et al. (2013a) \\
\hline Coprinopsis bellula & Hungary & L. Nagy & SZMC-NL-2341 & FM163176 & Nagy et al. (2011) \\
\hline Coprinopsis bicornis & $\begin{array}{l}\text { The } \\
\text { Netherlands }\end{array}$ & C.B. Uljé & Uljé 1216 HOLOTYPE & JX118690 & Nagy et al. (2013a) \\
\hline $\begin{array}{l}\text { Coprinopsis } \\
\text { brunneistrangulata }\end{array}$ & $\begin{array}{l}\text { North } \\
\text { America }\end{array}$ & $\begin{array}{l}\text { F. van de } \\
\text { Bogart }\end{array}$ & FVDB 3821 HOLOTYPE & JX118724 & Nagy et al. (2013a) \\
\hline Coprinopsis candidolanata & Italy & F. Doveri & ? HOLOTYPE & JX118682 & Nagy et al. (2013a) \\
\hline Coprinopsis canoceps & Sweden & L. Örstadius & LÖ 148-95 & KC992964 & Örstadius et al. (2015) \\
\hline Coprinopsis coniophora & N/A & L. Nagy & SZMC-NL-3414 & FN396122 & Nagy et al. $(2011,2013 b)$ \\
\hline Coprinopsis cortinata & N/A & L. Nagy & SZMC-NL-1621 & FN396121 & Nagy et al. $(2011,2013 b)$ \\
\hline Coprinopsis cothurnata & $\begin{array}{l}\text { USA } \\
\text { (Hawai'i) }\end{array}$ & D.E. Hemmes & SFSU DEH 548 & AY461833 & Keirle et al. (2004) \\
\hline Coprinopsis filamentifer & N/A & L. Nagy & SZMC-NL-0380 & HQ847035 & Nagy et al. (2013b) \\
\hline Coprinopsis fusispora & Hungary & L. Nagy & $\begin{array}{l}\text { SZMC-NL-1227 } \\
\text { HOLOTYPE }\end{array}$ & JX118740 & Nagy et al. (2013a) \\
\hline Coprinopsis goudensis & N/A & L. Nagy & SZMC-NL-4139 & FN396128 & Nagy et al. (2011) \\
\hline Coprinopsis insignis & Hungary & L. Nagy & SZMC-NL-1510 & JX118738 & Nagy et al. (2013a) \\
\hline Coprinopsis jonesii & Sweden & L. Nagy & SZMC-NL-0154 & JX118726 & Nagy et al. (2013a) \\
\hline Coprinopsis lagopides & N/A & N/A & N/A & KM373258 & Elwess et al. (2016) \\
\hline Coprinopsis lagopus & Hungary & L. Nagy & SZMC-NL-0995 & HQ847020 & Nagy et al. (2013a) \\
\hline Coprinopsis lagopus & Hungary & L. Nagy & SZMC-NL-2493 & HQ872014 & Nagy et al. (2013a) \\
\hline Coprinopsis lagopus & Hungary & L. Nagy & SZMC-NL-1558 & JX118711 & Nagy et al. (2013a) \\
\hline Coprinopsis lagopus & Sweden & L. Nagy & SZMC-NL-3658 & JX118717 & Nagy et al. (2013a) \\
\hline Coprinopsis macrocephala & N/A & L. Nagy & SZMC-NL-1376 & FN396126 & Nagy et al. (2011) \\
\hline Coprinopsis marcescibilis & Hungary & L. Nagy & SZMC-NL-2140 & FM878020 & Nagy et al. (2010a) \\
\hline Coprinopsis mиsae & Denmark & J. Vesterholt & JV 06-179 HOLOTYPE & КС992965 & Örstadius et al. (2015) \\
\hline Coprinopsis neolagopus & N/A & N/A & NBRC 100013 & AB097564 & $\begin{array}{l}\text { Suzuki et al. (unpublished } \\
\text { data) }\end{array}$ \\
\hline Coprinopsis nevillei & France & G. Garcia & $\begin{array}{l}\text { GG } 08090401 \text { (LIP) } \\
\text { HOLOTYPE }\end{array}$ & HM126488 & Garcia \& Vellinga (2010) \\
\hline Coprinopsis nivea & Italy & E. Bizio & MCVE 4585 & JF907848 & Osmundson et al. (2013) \\
\hline Coprinopsis pachyderma & $\begin{array}{l}\text { North } \\
\text { America }\end{array}$ & $\begin{array}{l}\text { F. van de } \\
\text { Bogart }\end{array}$ & FVDB 3237 HOLOTYPE & JX118731 & Nagy et al. (2013a) \\
\hline Coprinopsis pannucioides & N/A & L. Nagy & SZMC-NL-3528 & FN396143 & Nagy et al. (2011) \\
\hline Coprinopsis poliomallus & Hungary & L. Nagy & SZMC-NL-2336 & FM163182 & Nagy et al. (2009) \\
\hline Coprinopsis pseudonivea & Hungary & L. Nagy & SZMC-NL-2340 & FM163181 & Nagy et al. (2009) \\
\hline Coprinopsis pseudoradiata & Norway & L. Nagy & SZMC-NL-0956 & JX118687 & Nagy et al. (2013a) \\
\hline Coprinopsis radiata & Hungary & L. Nagy & SZMC-NL-1244 & HQ847024 & Nagy et al. (2013a) \\
\hline $\begin{array}{l}\text { Coprinopsis } \\
\quad \text { rugosomagnispora }\end{array}$ & Poland & M. Gryc & $\begin{array}{l}\text { KRAM F-58717 } \\
\text { HOLOTYPE }\end{array}$ & KX276859 & this study \\
\hline Coprinopsis scobicola & $\begin{array}{l}\text { United } \\
\text { Kingdom }\end{array}$ & P.D. Orton & Orton 964 HOLOTYPE & HQ847021 & Nagy et al. (2013a) \\
\hline
\end{tabular}


Table 1 continued

\begin{tabular}{|c|c|c|c|c|c|}
\hline Species & Country & Collector & Voucher & $\begin{array}{l}\text { GenBank acc. no. } \\
\text { (ITS) }\end{array}$ & References \\
\hline Coprinopsis submicrospora & N/A & L. Nagy & SZMC-NL-0635 & HQ847053 & Nagy et al. (2013b) \\
\hline Coprinopsis tectispora & $\begin{array}{l}\text { North } \\
\text { America }\end{array}$ & $\begin{array}{l}\text { F. van de } \\
\text { Bogart }\end{array}$ & FVDB 6016 HOLOTYPE & JX118665 & Nagy et al. (2013a) \\
\hline Coprinopsis udicola & Germany & A. Melzer & AM 1240 HOLOTYPE & KC992967 & Örstadius et al. (2015) \\
\hline Coprinopsis utrifer & N/A & L. Nagy & SZMC-NL-0591 & FN396140 & Nagy et al. $(2011,2013 b)$ \\
\hline Coprinopsis villosa & Germany & L. Nagy & SZMC-NL-1758 & HQ847031 & Nagy et al. (2013a) \\
\hline $\begin{array}{l}\text { Coprinus fissolanatus nom. } \\
\text { prov. }\end{array}$ & $\begin{array}{l}\text { The } \\
\text { Netherlands }\end{array}$ & C.B. Uljé & Daams 71-121 & JX118733 & Nagy et al. (2013a) \\
\hline
\end{tabular}

N/A not available

Fig. 2 Basidiocarps of Coprinopsis rugosomagnispora from the Puszcza Knyszynska forest, NE Poland: a, b general view; c lamellae; d, e young basidiocarps; f old specimen
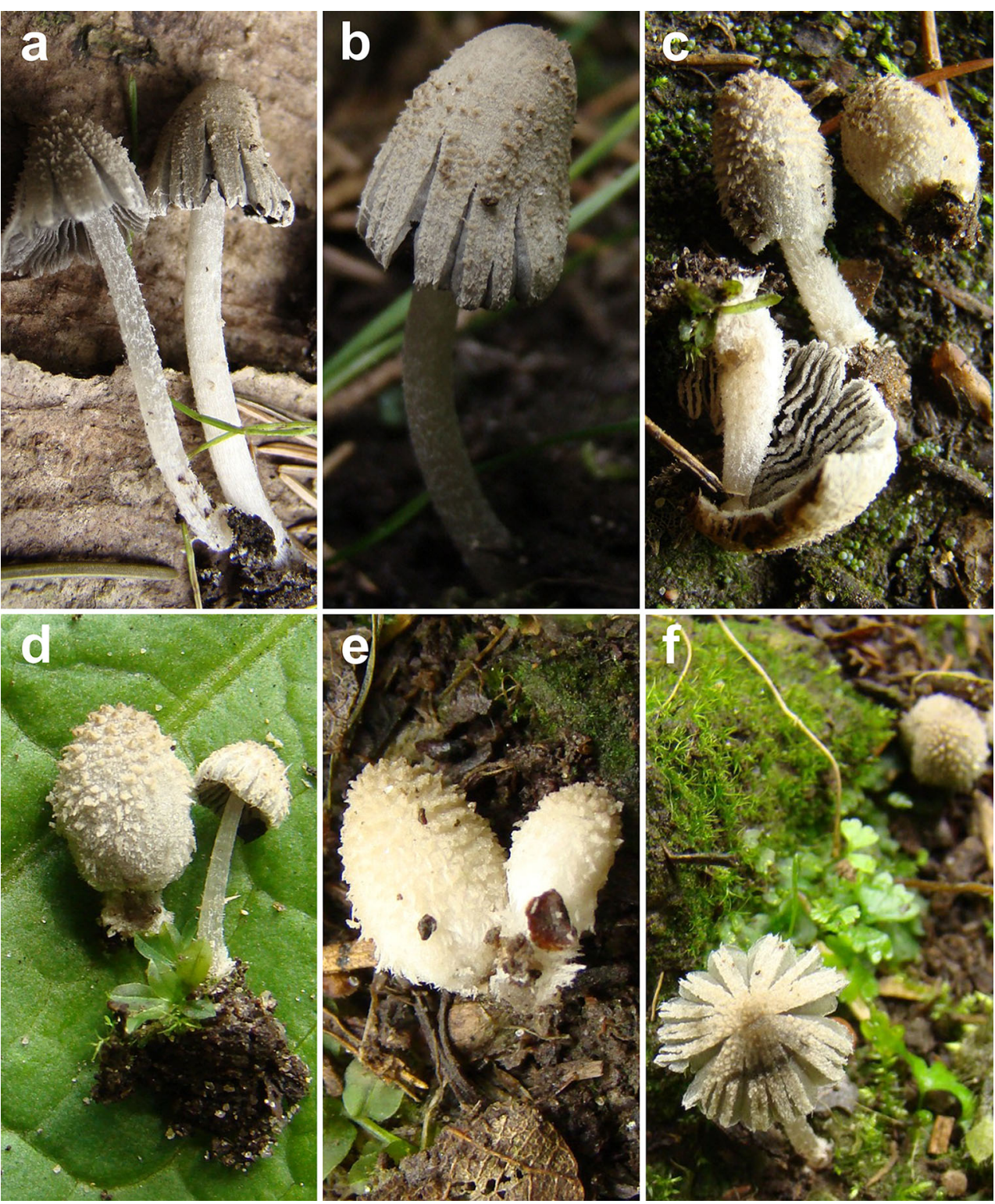

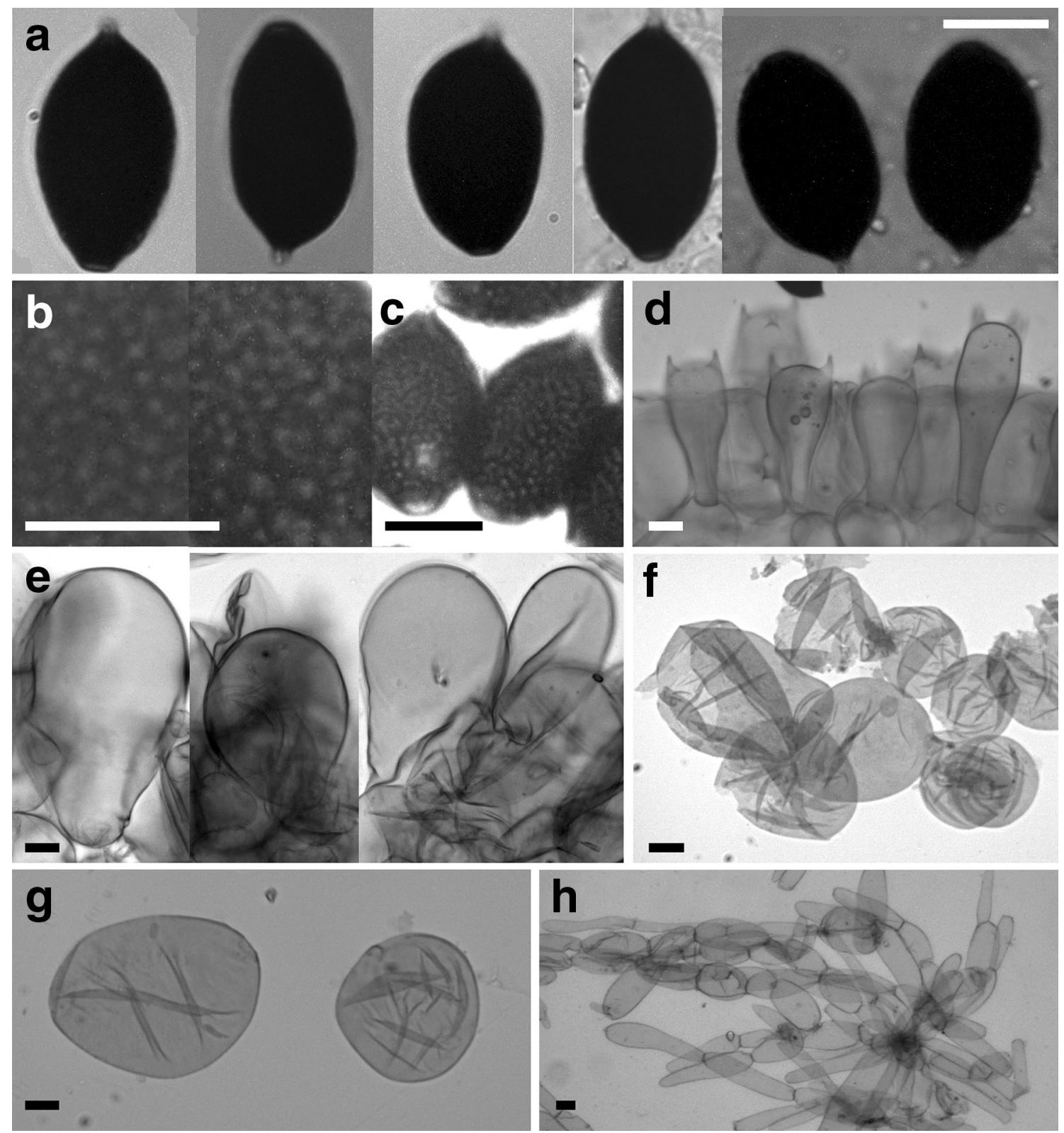

Fig. 3 Microcharacters of Coprinopsis rugosomagnispora (holotype: KRAM F-58717): a spores; b, c ornamentation of immature spore surface; d basidia; e cheilocystidia; $\mathbf{f}, \mathbf{g}$ veil from pileus surface; $\mathbf{h}$ veil from stipe surface. Scale bars $10 \mu \mathrm{m}$

spherical elements emerging from thin hyphae), but particular cells of veil elements are (sub)globose in shape, as in the subsection Nivei (in the subsection Lanatuli, the veil elements are cylindrical to fusiform). Remarkably, the molecular phylogenetic analyses indicate a relationship of C. rugosomagnispora with the species possessing morphological traits typical for the subsection Lanatuli. None of the described species of the subsection Nivei have ornamented spores. In the subsection Lanatuli, ornamented spores are characteristic only for $C$. insignis and $C$. calospora (Bas \& Uljé) Redhead, Vilgalys \& Moncalvo. Indeed, the molecular phylogenetic analyses indicated that
C. rugosomagnispora and $C$. insignis are closely related (Fig. 1). In contrast, C. calospora is related to C. cinerea (Schaeff.) Redhead, Vilgalys \& Moncalvo as shown by Nagy et al. (2013a). The well-developed episporium in Coprinopsis rugosomagnispora is not typical for species assigned to the subsections Lanatuli and Nivei but is characteristic for Coprinopsis species from the subsection Narcotici of Coprinus s.l. (Uljé 2005); however, ornamented spores are rare in that subsection (Uljé 2005). It is noteworthy that Coprinopsis rugosomagnispora is phylogenetically related to $C$. fusispora and $C$. insignis that were assigned to the so-called Atramentarii clade (Nagy et al. 
Fig. 4 SEM micrographs of the spores of Coprinopsis rugosomagnispora (holotype: KRAM F-58717): a, d general view; b ornamentation pattern; c germ pore close-up. Scale bars: $10 \mu \mathrm{m}$
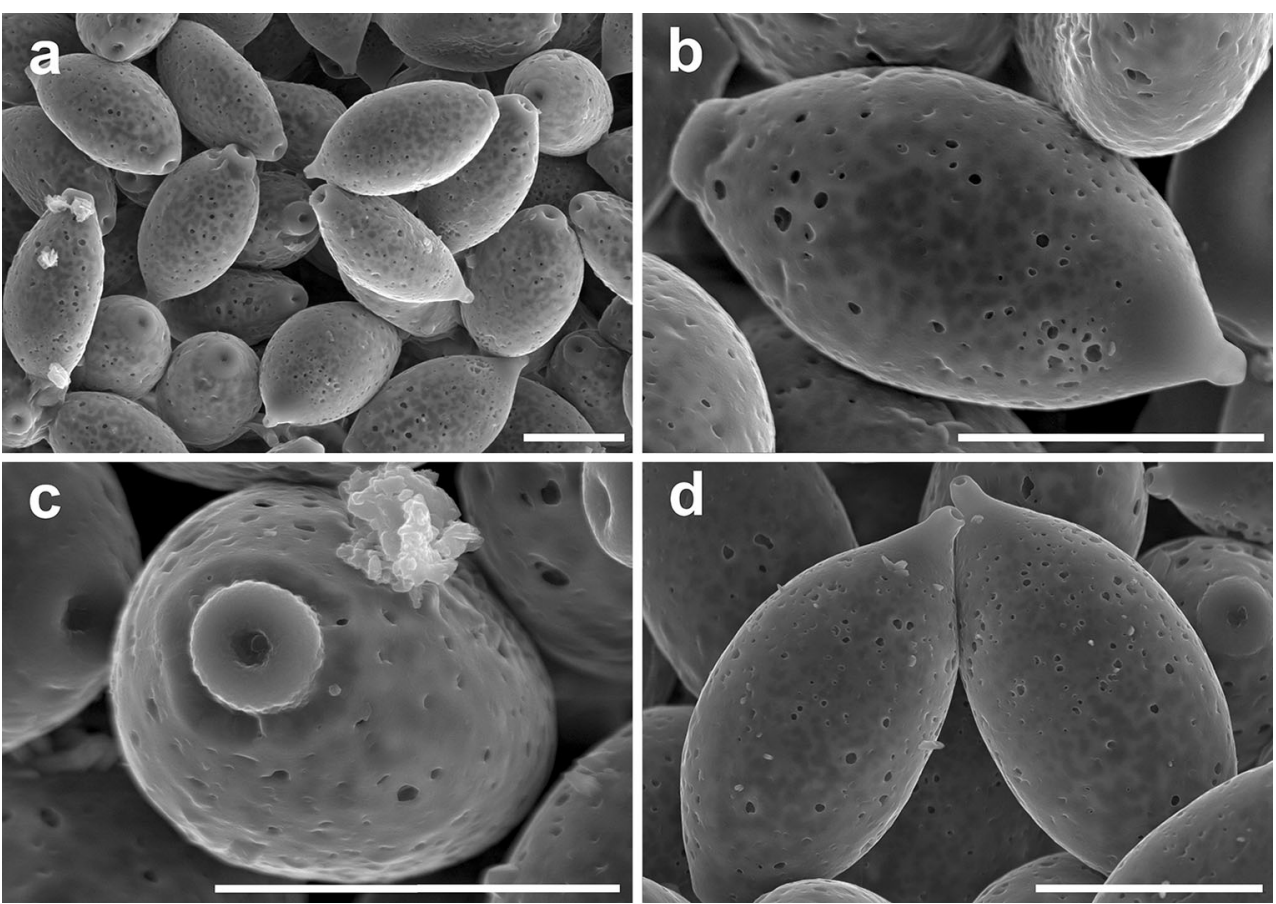

2013a), despite of their morphological similarity to mezmbers of the subsection Lanatuli. Since the sectional and subsectional taxonomy within Coprinopsis is still not clarified, we tentatively retain with assignment of these species to the morphological subsection Lanatuli (Fig. 1).

The spore ornamentation pattern of Coprinopsis rugosomagnispora is unique among coprinoid fungi. Some of the recently described or redescribed species have warts $(C$. echinospora (Buller) Redhead, Vilgalys \& Moncalvo and related taxa, C. insignis) or nodules (C. calospora) (Uljé 2005; Raut et al. 2011; Fukiharu et al. 2011, 2013, 2014). Spores of Coprinellus species may have warts (Coprinellus silvaticus (Peck) Gminder) or low crest and rows composed from minute warts (Coprinellus verrucispermus (Joss. \& Enderle) Redhead, Vilgalys \& Moncalvo) (Uljé 2005; Nagy et al. 2012), while spores of Coprinopsis rugosomagnispora are densely pitted. This pattern is poorly visible on mature spores, due to their dark color, but it is easy to observe on immature spores when they are just redbrown in color. The ornamentation is also hardly visible on SEM micrographs, as the episporium is smooth and persistent, so only some darken areas or rarely hollows are present on the spore surface (Fig. 4). The spore size of $C$. rugosomagnispora is larger than in all known coprinoid taxa. Only Coprinus xerophilus Bogart and Coprinus sterquilinus (Fr.) Fr. have spores, which may be longer than $20 \mu \mathrm{m}$, but both these taxa differ by having a smooth spore surface and different veil structure (Uljé 2005). This makes the species newly described here easy to recognize, even if the collection is incomplete, namely autolysed and decayed.

\section{Taxonomic treatment}

Coprinopsis rugosomagnispora Gierczyk, Pietras, Piątek, Gryc, Czerniawski \& Rodriguez-Flakus, sp. nov.-TYPE: Poland, Podlaskie Province: Puszcza Knyszyńska forest, S from Supraśl village, on soil in mixed forest, 24 Aug 2013, M. Gryc s.n. (holotype: KRAM F-58717!; isotype: BGF/ BF/MG/130824/0005!; GenBank: KX276859). [MycoBank no. MB 820057].

Etymology: The Latin rugoso refers to the ornamentation of the spores, magni refers to their large dimensions, and spora refers to spore.

Description: Basidiocarps small (Fig. 2). Pileus 5-10 × 4-8 mm, first subglobose to broadly ellipsoid, expanding to convex campanulate, up to $15 \mathrm{~mm}$ broad; surface radially striate to plicate, covered by mealy to granulose veil forming squarrose, conical to nipple-shaped warts, veil whitish (1B2) to ocher-brown (6D6). Lamellae free, crowded ( $L=40-60)$, first whitish, then gray, finally black, deliquescent and undergoing autolysis with age. Lamellar edge strongly pruinose (Fig. 2c), white. Stipe 10-30 × 1-1.5 mm, white, covered by white fibrils, rather fragile, hollow. Stipe base equal, not rooting. Flesh very thin, white, odorless. Basidiospores (19.5-)21.0-21.5 $(-24.0) \times(12.0-) 13.0-13.5(-15.0) \times(12.0-) 12.5-13.0$ $(-15.0) \mu \mathrm{m}$ (av. $21.3 \times 13.1 \times 12.9 \mu \mathrm{m}), Q=1.56-1.64$ (av. 1.60), black in mass, very dark red-brown (10G8) to almost black under light microscope, limoniform with prominent apiculus (apiculus length 1.3-2.0 $\mu \mathrm{m}$ ) and with central, papillate germ pore $2.0-2.5 \mu \mathrm{m}$ broad, not 
Fig. 5 Drawings of microcharacters of Coprinopsis rugosomagnispora (holotype: KRAM F-58717): a spores; b basidia; c veil from the stipe surface; d cheilocystidia; e veil from pileus surface. Scale bars $10 \mu \mathrm{m}$
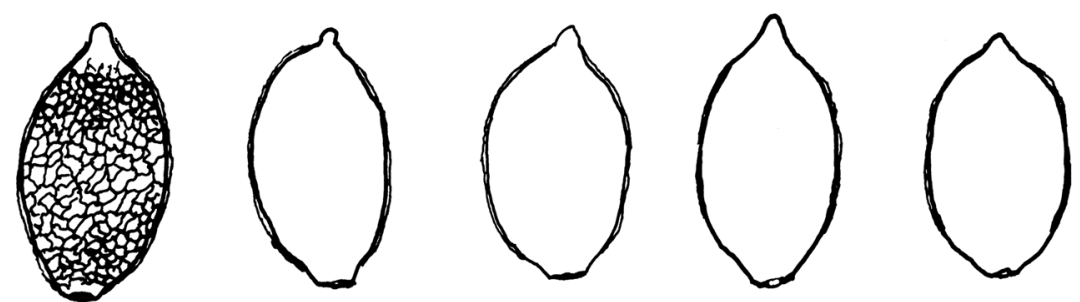

a



b



C
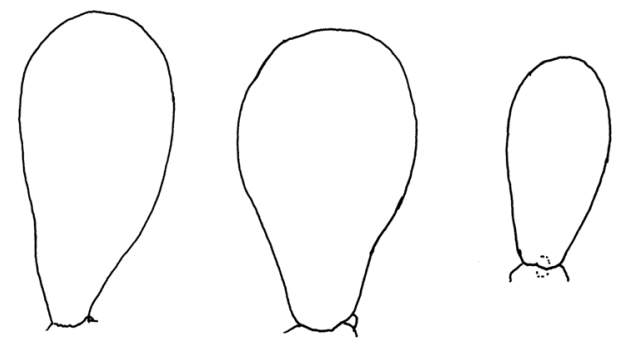

d
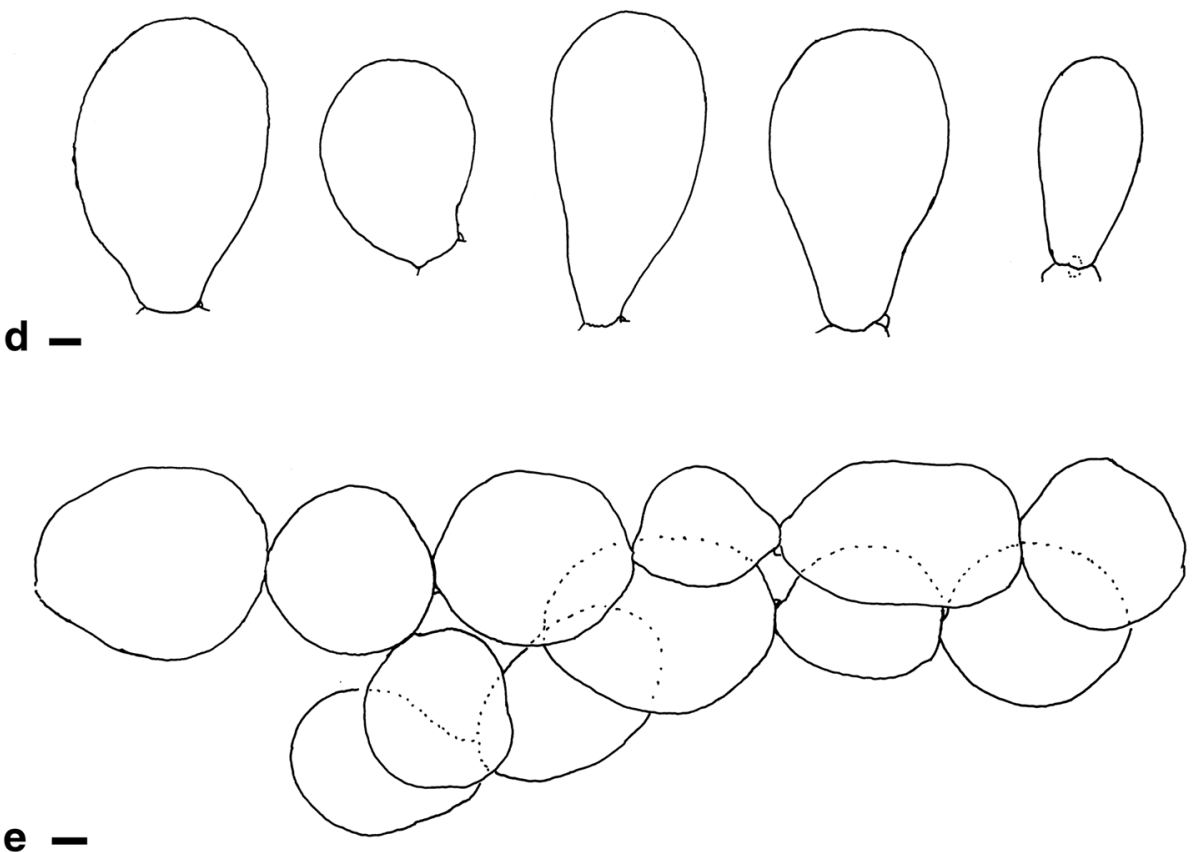

flattened (Figs. 3a, 4, 5a). Ornamentation of spore surface prominent, up to $0.5 \mu \mathrm{m}$ high, covered with smooth, tight, persistent episporium. Ornament composed of hollows that make rugulose or pitted appearance of the spore wall (pitted spores; Figs. 3b, c, 5a). Basidia 4-spored, dimorphic, long type $52-56 \times 16-17 \mu \mathrm{m}$, short type $34-38 \times 15-16 \mu \mathrm{m} \quad$ (measured without sterigmata; Figs. 3d, 5b). Sterigmata 5.0-5.5 $\mu \mathrm{m}$ long. Cheilocystidia $50-100 \times 32-60 \mu \mathrm{m}$, subglobose, broadly ellipsoid to broadly clavate (Figs. 3e, 5d). Pleuro-, caulo- and pileocystidia absent. Veil on the pileus composed of (sub)globose to broadly ellipsoid, smooth, thin-walled, colorless elements, $\quad 24-60 \times 24-45 \mu \mathrm{m}$, and with scattered cylindrical hyphae up to $25 \mu \mathrm{m}$ broad (Figs. 3f, g, 5e). Stipe covering made up of cylindrical hyphae, $35-85 \times 10-30 \mu \mathrm{m}$, forming chains, not or moderately constricted at septa. On upper part of the stipe veil consists also of broadly ellipsoid elements up to $35 \mu \mathrm{m}$ broad. Terminal elements of the stipe veil conically tapering with obtuse, 5-8 $\mu \mathrm{m}$ broad apex (Figs. 3h, 5c). Clamp-connections present.

Diagnosis: Species characterized by a veil composed of smooth, globose elements in chains, 4-spored, large basidia and rugulose (pitted), limoniform spores up to $24 \mu \mathrm{m}$ long, with a tight episporium. 




Fig. 6 Known localities of Coprinopsis rugosomagnispora in Poland $(\bullet)$

Phenology: Specimens found between July and September.

Distribution area: Poland-Podlaskie Province and Małopolska Province. Coprinopsis rugosomagnisporaknown localities in Poland are over $450 \mathrm{~km}$ apart (Fig. 6); therefore, it is not a local species and should occur in other parts of Poland as well as in other European countries. Further studies are needed to determine the distribution of Coprinopsis rugosomagnispora.

Habitats: Coprinopsis rugosomagnispora grows in forests. It has been found in both coniferous forest and mixed forest dominated by deciduous trees. At all three known stands, it was found on wet, muddy soils.

Additional specimens examined: Poland, Podlaskie Province: Puszcza Knyszyńska forest, $2 \mathrm{~km}$ S from Supraśl village, near Krasny Las forest ranger's lodge, on muddy soil on dirt road side in mixed forest (Picea abies (L.) H.Karst., Alnus glutinosa (L.) Gaertn.), 7 Jul 2013, M. Gryc s.n. (BGF/BF/MG/130707/0002!), 24 Aug 2013, M. Gryc s.n. (BGF/BF/MG/130824/0005!), 1 Sep 2013, M. Gryc s.n. (BGF/BF/MG/130901/0002!); Poland, Podlaskie Province: Puszcza Knyszyńska forest, $6 \mathrm{~km}$ NE from Supraśl village, near on muddy soil on dirt roadside in mixed forest, Sep 2013, M. Gryc s.n. (BGF/BF/MG/130901/0002!); Poland, Małopolska Province: Pogórze Wielickie foothills, Jasienica near Sułkowice village, on clayed soil mixed with sandstone rubble in silver fir (Abies alba Mill.) forest, Aug 2010, W. Czerniawski s.n. (BGF/BF/WCz/100801/0002!).

Acknowledgements We thank Anna Łatkiewicz (Kraków) for help with SEM micrographs. The work of Marcin Piątek and Pamela
Rodriguez-Flakus was partly supported by the statutory funds of the W. Szafer Institute of Botany, Polish Academy of Sciences, Kraków, Poland.

\section{Compliance with ethical standards}

Conflict of interest The authors declare that they have no conflict of interest.

Open Access This article is distributed under the terms of the Creative Commons Attribution 4.0 International License (http://crea tivecommons.org/licenses/by/4.0/), which permits unrestricted use, distribution, and reproduction in any medium, provided you give appropriate credit to the original author(s) and the source, provide a link to the Creative Commons license, and indicate if changes were made.

\section{References}

Altschul SF, Madden TL, Schäffer AA, Zhang J, Zhang Z, Miller W, Lipman DJ (1997) Gapped BLAST and PSI-BLAST: a new generation of protein database search programs. Nucl Acids Res 25:3389-3402. doi:10.1093/nar/25.17.3389

Citérin M (1992) Clé analytique du genre Coprinus Pers. Doc Mycol 22: $1-28$

Edgar RC (2004) MUSCLE: a multiple sequence alignment method with reduced time and space complexity. BMC Bioinform 5:113. doi:10.1186/1471-2105-5-113

Elwess NL, Levere S, Latourelle SM (2016) DNA barcoding and phylogenetic characterization of mushrooms within the Adirondack Park. Int J Res Developm Organ J Agric Res 2:28-43

Fukiharu T, Bougher N, Buchanan P, Suzuki A, Tanaka C, Sagara N (2011) Coprinopsis austrophlyctidospora sp. nov., an agaric ammonia fungus from Southern Hemisphere plantations and natural forests. Mycoscience 52:137-142. doi:10.1007/s10267-010-0077-0

Fukiharu T, Shimizu K, Li R, Raut JK, Yamakoshi S, Horie Y, Kinjo N (2013) Coprinopsis novorugosobispora sp. nov., an agaric ammonia fungus from Beijing, China. Mycoscience 54:226-230. doi:10.1016/j.myc.2012.09.014

Fukiharu T, Shimizu K, Utsunomiya H, Raut JK, Goto R, Okamoto T, Kato M, Horigome R, Furuki T, Kinjo N (2014) Coprinopsis asiaticiphlyctidospora sp. nov., an agaric ammonia fungus from Amami and Okinawa, southern Japan. Mycoscience 55:355-360. doi:10.1016/j.myc.2013.12.002

Garcia G, Vellinga EC (2010) Une nouvelle espèce de coprin sur tiges de Polygonatum multiflorum: Coprinopsis nevillei sp. nov. Bull Féd Assoc Mycol Médit 37:37-58

Geml J, Timling I, Robinson CH, Lennon N, Nusbaum HC, Brochmann C, Noordeloos ME, Taylo DL (2012) An arctic community of symbiotic fungi assembled by long-distance dispersers: phylogenetic diversity of ectomycorrhizal basidiomycetes in Svalbard based on soil and sporocarp DNA. J Biogeogr 39:74-88. doi:10.1111/j.1365-2699.2011.02588.x

Hallen HE, Watling R, Adams GC (2003) Taxonomy and toxicity of Conocybe lactea and related species. Mycol Res 107:969-979. doi: $10.1017 /$ S0953756203008190

Hopple JS Jr, Vilgalys R (1999) Phylogenetic relationships in the mushroom genus Coprinus and dark-spored allies based on sequence data from the nuclear gene coding for the large ribosomal subunit RNA: divergent domains, outgroups, and monophyly. Molec Phylogen Evol 13:1-19. doi:10.1006/mpev. 1999.0634 
Huelsenbeck JP, Ronquist F (2003) MRBAYES 3: Bayesian phylogenetic inference under mixed models. Bioinformatics 19:1572-1574. doi:10.1093/bioinformatics/btg180

Keirle MR, Hemmes DE, Desjardin DE (2004) Agaricales of the Hawaiian Islands. 8. Agaricaceae: Coprinus and Podaxis; Psathyrellaceae: Coprinopsis, Coprinellus and Parasola. Fungal Diversity 15:33-124

Kornerup A, Wanscher JH (1984) Methuen handbook of colour, 3rd edn. Methuen London Ltd, Copenhagen

Lanfear R, Calcott B, Ho SYW, Guidon S (2012) PartitionFinder: combined selection of partitioning schemes and substitution models for phylogenetic analyses. Molec Biol Evol 29:1695-1701. doi:10.1093/molbev/mss020

Lange JE (1915) Studies in the Agarics of Denmark. Part II. Amanita, Lepiota, Coprinus. Dansk Bot Ark 3:1-53

Larsson E, Örstadius L (2008) Fourteen coprophilous species of Psathyrella identified in the Nordic countries using morphology and nuclear rDNA sequence data. Mycol Res 112:1165-1185. doi:10.1016/j.mycres.2008.04.003

Moncalvo JM, Vilgalys R, Redhead SA, Johnson JE, James TY, Aime MC, Hofstetter V, Verduin SJW, Larsson E, Baroni TJ, Thorn RG, Jacobsson S, Clémençon H, Miller OK Jr (2002) One hundred and seventeen clades of euagarics. Molec Phylogen Evol 23:357-400. doi:10.1016/S1055-7903(02)00027-1

Nagy GL, Kocsubé S, Papp T, Vágvölgyi C (2009) Phylogeny and character evolution of the coprinoid mushroom genus Parasola as inferred from LSU and ITS nrDNA sequence data. Persoonia 22:28-37. doi:10.3767/003158509X422434

Nagy LG, Urban A, Örstadius L, Papp T, Larsson E, Vágvölgyi C (2010a) The evolution of autodigestion in the mushroom family Psathyrellaceae (Agaricales) inferred from maximum likelihood and Bayesian methods. Molec Phylogen Evol 57:1037-1048. doi:10.1016/j.ympev.2010.08.022

Nagy LG, Vágvölgyi C, Papp T (2010b) Type studies and nomenclatural revisions in Parasola (Psathyrellaceae) and related taxa. Mycotaxon 112:103-141. doi:10.5248/112.103

Nagy LG, Walther G, Házi J, Vágvölgyi C, Papp T (2011) Understanding the evolutionary processes of fungal fruiting bodies: correlated evolution and divergence times in the Psathyrellaceae. Syst Biol 60:303-317. doi:10.1093/sysbio/ syr005

Nagy LG, Házi J, Vágvölgyi C, Papp T (2012) Phylogeny and species delimitation in the genus Coprinellus with special emphasis on the haired species. Mycologia 104:254-275. doi:10.3852/11-149

Nagy LG, Desjardin DE, Vágvölgyi C, Kemp R, Papp T (2013a) Phylogenetic analyses of Coprinopsis sections Lanatuli and Atramentarii identify multiple species within morphologically defined taxa. Mycologia 105:112-124. doi:10.3852/12-136

Nagy LG, Vágvölgyi C, Papp T (2013b) Morphological characterization of clades of the Psathyrellaceae (Agaricales) inferred from a multigene phylogeny. Mycol Progr 12:505-517. doi:10. 1007/s11557-012-0857-3

Navarro-González M, Domingo-Martínez A, Navarro-González SS, Beutelmann P, Kües U (2006) Monstrosities under the inkcap mushrooms. In: Pisabarro AG, Ramírez L (eds) Genetics and cellular biology of Basidiomycetes VI. Universidad Pública de Navarra, Pamplona, pp 113-122

Örstadius L, Ryberg M, Larsson E (2015) Molecular phylogenetics and taxonomy in Psathyrellaceae (Agaricales) with focus on psathyrelloid species: introduction of three new genera and 18 new species. Mycol Progr 14:25. doi:10.1007/s11557-015-1047-x

Osmundson TW, Robert VA, Schoch CL, Baker LJ, Smith A, Robich G, Mizzan L, Garbelotto MM (2013) Filling gaps in biodiversity knowledge for macrofungi: contributions and assessment of an herbarium collection DNA barcode sequencing project. PLoS ONE 8:e62419. doi:10.1371/journal.pone.0062419

Padamsee M, Matheny PB, Dentinger BTM, McLaughlin DJ (2008) The mushroom family Psathyrellaceae: evidence for large-scale polyphyly of the genus Psathyrella. Molec Phylogen Evol 46:415-429. doi:10.1016/j.ympev.2007.11.004

Page RDM (1996) TREEVIEW: an application to display phylogenetic trees on personal computers. Computer Applic Biosci 12:357-358. doi:10.1093/bioinformatics/12.4.357

Raut JK, Suzuki A, Fukiharu T, Shimizu K, Kawamoto S, Tanaka C (2011) Coprinopsis neophlyctidospora sp. nov., a new ammonia fungus from boreal forests in Canada. Mycotaxon 115:227-238. doi: $10.5248 / 115.227$

Ruiz A, Iglesias P, Rodríguez B, Muñoz G (2013) Coprinopsis xenobia, descripción y primeras localizaciones en España. Comparación filogenética con Coprinopsis luteocephala. Bol Micol FAMCAL 7:63-70

Silvestro D, Michalak I (2012) RaxmlGUI: a graphical front-end for RAxML. Organisms Diversity Evol 12:335-337. doi:10.1007/ s13127-011-0056-0

Uljé CB (2005) Coprinus. In: Noordeloos ME, Kuyper TW, Vellinga EC (eds) Flora Agaricina Neerlandica, vol 6, Critical monograps on families of agarics and boleti occurring in the Netherlands. Taylor \& Francis, Boca Raton, pp 22-109

Vesterholt J (2012) Coprinopsis P. Karst. In: Knudsen H, Vesterholt J (eds) Funga Nordica. Agaricoid, boletoid, clavarioid, cyphelloid and gasteroid genera. Nordsvamp, Copenhagen, pp 672-687

White TJ, Bruns T, Lee S, Taylor JW (1990) Amplification and direct sequencing of fungal ribosomal RNA genes for phylogenetics. In: Innis MA, Gelfand DH, Sninsky JJ, White TJ (eds) PCR protocols: a guide to methods and applications, vol. 4. Academic, New York, pp 315-322

Yang ZL, Matheny PB, Ge ZW, Slot JC, Hibbett DS (2005) New Asian species of the genus Anamika (euagarics, hebelomatoid clade) based on morphology and ribosomal DNA sequences. Mycol Res 109:1259-1267. doi:10.1017/S0953756205003758 